\title{
Sosialisasi Perbankan Syariah Ditengah Pandemi Covid-19 Di Masjid Nuruddin Desa Gelebak Dalam Kecamatan Rambutan Kabupaten Banyuasin Palembang
}

\section{Choiriyah}

Program Studi Perbankan Syariah STEBIS IGM Palembang

Email: choi@ stebisigm.ac.id

\begin{abstract}
This community service activity discussed the introduction of Islamic Banking in the midst of the Covid-19 pandemic at the Nuruddin Mosque, Gelebak Dalam Village, Rambutan District, Banyuasin Regency, Palembang. The purpose of this community service activity is to provide an introduction to Sharia Banking to the people of Gelebak Dalam Village with the hope that the community or socialization participants can understand the current existence of Islamic banking which is everywhere both in villages and in urban areas. The socialization participants can also find out that sharia talks are currently being discussed by many people. Sharia banking is a banking system developed based on sharia or Islamic law.
\end{abstract}

Keywords: Sharia Banking, Amid the Covid-19 Pandemic

\begin{abstract}
Abstrak
Kegiatan pengabdian masyarakat ini membahas tentang pengenalan Perbankan Syariah ditengah pandemi Covid-19 di Masjid Nuruddin Desa Gelebak Dalam Kecamatan Rambutan Kabupaten Banyuasin Palembang. Tujuan kegiatan pengabdian masyarakat ini memberikan pengenalan tentang Perbankan Syariah kepada masyarakat Desa Gelebak Dalam dengan harapan masyarakat ataupun peserta sosialisasi bisa memahami akan adanya perbankan syariah saat ini yang sudah ada dimana-mana baik di desa maupun di perkotaan. Peserta sosialisasai juga bisa mengetahui bahwa perbakan syarian saat ini sudah banyak di perbincangkan oleh halayak ramai. Perbankan Syariah merupakan suatu sistem perbankan yang dikembangkan berdasarkan syariah atau hukum islam.
\end{abstract}

Kata Kunci: Perbankan Syariah, ditengah Pandemi Covid-19

\section{Pendahuluan}

Dasar perbankan syariah mengacu kepada ajaran agama Islam yang bersumber pada al-Qur'an, al-Hadits/ as-Sunnah, dan Ijtihad. Ajaran agama Islam yang bersumber pada wahyu Ilahi dan sunaturosul mengajarkan kepada umatnya untuk berusaha mendapatkan kehidupan yang baik di dunia yang sekaligus memperoleh kehidupan yang baik di akhirat. Hal ini berarti, bahwa dalam mengerjakan kehidupan di dunia tidak dapat dilakukan dengan menghalalkan segala cara, tapi harus dilakukan melalui gerakan amal saleh. "Bank Syariah adalah bank yang kegiatan usahanya dilakukan berdasarkan prinsip syariah. Sedangkan prinsip syariah adalah aturan perjanjian berdasarkan hukum Islam" (UU No. 21/2008 tentang Perbankan Syariah). Bank Islam atau selanjutnya disebut dengan Bank Syariah, adalah bank yang beroperasi dengan tidak mengandalkan pada bunga. 
Bank syariah juga dapat diartikan sebagai lembaga keuangan/perbankan yang operasional dan produknya dikembangkan berlandaskan Al-Qur'an dan Hadits Nabi SAW.

Antonio dan Perwataatmadja membedakan menjadi dua pengertian, yaitu Bank Islam dan Bank yang beroperasi dengan prinsip syariah Islam (UU No. 21 Tahun 2008 tentang Perbankan Syariah). Bank Syariah adalah bank yang beroperasi dengan tidak mengandalkan pada bunga. Bank Islam atau biasa disebut dengan Bank Tanpa Bunga, adalah lembaga keuangan/perbankan yang operasional dan produknya dikembangkan berlandaskan pada al-Quran dan Hadits Nabi SAW, dengan kata lain Bank Syariah adalah lembaga keuangan yang memiliki usaha pokok memberikan pembiayaan dan jasa-jasa lainnya dalam lalu lintas pembayaran serta peredaran uang yang pengoperasiannya disesuaikan dengan prinsip syariat Islam. Bank syariah menghindari sistem bunga dalam mengoperasikan usahanya. Keberadaan bank syariah/bank Islam dapat dijadikan sebagai solusi alternatif terhadap persoalaan tentang adanya pertentangan antara bunga dengan riba (Muhammad, 2005 : 1). Secara umum konsep perbankan syariah menawarkan sistem perekonomian yang sesuai dengan syariat Islam/prinsip syariah. (https://fachriadha.silabus-makul-bank-dan-lembaga-keu.html).

Perkembangan perbankan syariah di Indonesia sekarang ini mengalami kemajuan yang sangat pesat sebagai salah satu infrastruktur sistem perbankan nasional. Eksistensi bank syariah di Indonesia secara formal dimulai sejak diberlakukannya UU No. 10 tahun 1998 tentang perbankan di Indonesia yang merupakan hasil revisi dari UU No. 7 tahun 1998. UU No. 10 tahun 1998 ini menjadi dasar hukum akan keberadaan dual banking system yaitu beroperasinya system perbankan konvensional yang didampingi dengan perbankan syariah di Indonesia. Perkembangan ini diikuti oleh beredarnya jaringan kantor perbankan syariah yang tersebar di seluruh wilayah Indonesia. Menurut data perbankan syariah 2016, saat ini sudah ada 13 Bank Umum Syariah (BUS), 21 Bank 5 Syariah dalam bentuk Unit Usaha Syariah (UUS), dan 166 Bank Pembiayaan Rakyat Syariah (BPRS). Hal ini dapat dijadikan indikator penting kemampuan bank syariah dalam menghasilkan profit (https://core.ac.uk/pdf/148617413.pdf).

\section{Landasan Teori}

\section{a. Pengertian Perbankan Syariah}

Kata Bank dari kata banque dalam bahasa Perancis, dan dari kata banco dalam bahasa Italia yang berarti peti, lemari dan bangku ( M. Syafi'I Antonio, 2006 : 2). Pada umumnya yang dimaksud bank syariah adalah lembaga keuangan yang usaha pokoknya memberikan pembiayaan dan jasa-jasa lain dalam lalu lintas pembayaran serta peredaran uang yang beroperasi disesuaikan dengan prinsip-prinsip syariah. Oleh karena itu usaha bank akan selalu berkaitan dengan masalah uang sebagai perangkat utamanya. Bank syariah terdiri dari dua kata, yaitu bank dan syariah. Kata bank bermakna suatu lembaga keuangan yang berfungsi sebagai perantara keuangan dari kedua belah pihak yait pihak yang kelebihan dana dan pihak yang kekurangan dana. Kata syari'a dalam versi bank syariah adalah aturan peranjian berdasarkan yang dilakukan oleh pihak bank dan pihak lain untuk menyimpan dana dan atas pembiayaan kegiatan usaha dan kegiatan lainnya sesuai hukum islam. Maka bank syariah dapat diartikan sebagai suatu lembaga keuangaang berfungsi menjadi perantara bagi pihak yang berlebihan dan pihak yang membutuhkan dana untuk kegiatan usah atau kegiatan yang lainnya sesuai hukum islam. Dengan 
demikian, bank syariah adalah bank yang tidak mengandalkan bunga, dan oprasional produknya, baik penghimpunan maupun penyuluhan dananya dan lalu lintas pembayaran serta peredaran uang dari dan untuk debitur berdasarkan prinsipprinsip hukum islam ( Wangsawidjaya, 2012 : 15-16).

Sementara bank yang beroprasi sesuai prinsip syariah Islam adalah bank yang dalam operasinya mengikuti ketentuan-ketentan syari'at Islam, khususnya yang menyangkut dalam tata cara bermu'amalat itu dijauhinya praktek-prakteknya yang dikhawatirkan mengandung unsur-unsur riba untuk diisi dengan kegiatan-kegiatan investasi atas dasar bagi hasil dan pembiayaan perdagangan.

\section{b. Latar Belakang Kemunculan Bank Syariah}

Dalam sejarah diketahui bahwa Baitulmaal merupakan lembaga keuangan pertama yang ada pada zaman Rasulullah. Baitul Mal Wal wa Tamwil merupakan organisasi bisnis yang juga berperan social (Muhammad Ridwan,2004 : 126). Lembaga ini pertama kali hanya berfungsi untuk menyimpan harta kekayaan negara berupa zakat, infak, sedekah, pajak dan harta rampasan perang. Kemudian pada masa pemerintahan sahabat berkembang pula lembaga lain, yaitu Baitutamwil yang bergerak dalam urusan penampungan dana - dana masyarakat untuk diinvestasikan ke proyek - proyek atau pembiayaan perdagangan yang menguntungkan.

Baitutamwil ini pada akhirnya berkembang menjadi berbagai lembaga keuangan Islam yang cukup diperhitungkan di Timur Tengah. Akan tetapi penggunaan nama baitutamwil tidak bisa dengan mudah diterapkan di beberapa negara-negara Islam bekas jajahan negara-negara Eropa. Hal itu disebabkan istilah baitutamwil tidak dikenal dalam sistem perundang-undangan negara-negara tersebut yang kebanyakan mewarisi undang-undang negara yang menjajahnya. Oleh karena itu digunakan nama bank Islam untuk menggantikan nama baitutamwi (Nurul Huda dan Muhamad Heykal, 2013 : 25).

Tujuan utama pendirian lembaga keuangan berlandaskan syariah adalah sebagai upaya kaum muslimin untuk mendasari segenap aspek ekonominya berdasarkan aturan Al Quran dan As Sunnah. Upaya awal penerapan sistem profit and loss sharing tercatat di Pakistan dan Malaysia sekitar tahun 1940-an yang memulai eksistensinya dengan mengelola dana - dana jamaah haji dengan cara yang tidak sama dengan yang dilakukan bank konvensional. Rintisan institusional lainnya adalah lahirnya Mit Ghamr Lokal Saving Bank pada tahun 1963 di Kairo Mesir yang didirikan oleh Prof. Ahmed Najjar (M. Syafi'i Antonio. 2001 : 18-19 ).

Di negara Indonesia sendiri lembaga perbankan Islam pertama kali dikenal dengan nama baitulmaal yang merupakan bagian dari masjid dan pesantren. Fungsi dari baitulmaal ini adalah untuk menampung dana zakat, infak, dan sedekah serta beberapa fungsi lain seperti menampung berbagai dana-dana yang ada di kalangan masyarakat untuk kemudian diinvestasikan dengan sistem bagi hasil ataupun untuk membiayai perdagangan yang sebenarnya merupakan fungsi baitutamwil. Akan tetapi melihat kenyataan bahwa Indonesia adalah negara bekas jajahan Belanda yang mengadopsi peraturan perundang-undangan Belanda, maka lembaga tersebut tidak begitu dikenal. Oleh karena untuk menghindari masalah legalitas, maka dipakailah nama bank Islam atau bank syariah sebagaimana yang terjadi di beberapa negara Islam bekas jajahan Eropa (Nurul Huda dan Muhamad Heykal, $2013: 26)$.

Pada awal 1980-an diskusi mengenai bank syariah mulai dilakukan. Para tokoh yang terlibat adalah Karnaen A. Perwataatmadja, M. Dawam Rahardjo, A. M. 
Saefudin, M. Amien Azies, dan lain-lain. Mereka mulai melakukan beberapa uji coba seperti Baitutamwil Salman Bandung serta Koperasi Ridho Gusti di Jakarta. Akan tetapi prakarsa lebih khusus untuk mendirikan bank Islam baru pada tahun 1990. MUI pada tanggal 18-20 Agustus 1990 menyelenggarakan lokakarya bunga bank dan perbankan di cisarua bogor. Hasil lokakarya tersebut dibahas secara mendalam pada Munas IV MUI pada 22-25 Agustus 1990. Berdasarkan amanat Munas tersebut dibentuk kelompok kerja untuk mendirikan bank Islam Indonesia. Akhirnya berdirilah PT Bank Muamalat Indonesia pada tahun 1991 melalui akata pendirian yang ditandatangani pada tanggal 1 November 1991 (M. Syafi'i Antonio. $2001: 25)$.

\section{c. Fungsi Perbankan Syariah}

Dalam paradigma akuntansi Islam, secara garis besar terdiri atas 4 fungsi utama, hal ini termuat dalam buku "Bank Syariah Dari Teori Ke Praktik" karangan Muhamad Syafi'i Antonio, yaitu fungsi bank syariah sebagai manajemen investasi, fungsi bank syariah sebagai investasi, fungsi bank syariah sebagai jasa-jasa keuangan, dan fungsi bank syariah sebagai jasa sosial.

1. Fungsi bank syariah sebagai Manajemen investasi. Bank-bank syariah dapat melaksanakan fungsi ini berdasarkan kontrak mudharabah atau kontrak perwakilan. Menurut kontrak mudharabah, bank (dalam kapasitasnya sebagai mudharib, yaitu pihak yang melaksanakan investasi dana dari peihak lain) menerima presentase keuntungan hanya dalam kasus untung. Dalam ha terjadi kerugian, sepenuhnya menjadi risiko dana (shahibu mal), sedangkan bank tidak ikut menanggungnya.

2. Fungsi bank syariah sebagai Investasi. Bank-bank syariah menginvestasikan dana yang ditempatkan pada dunia usaha (baik dana modal maupun dana rekening investasi) dengan menggunakan aat-alat investasi yang konsisten dengan syariah. Di antara contohnya adalah kontrak murabahah, musyarakah, bai' as-salam, bai' al-istisna', ijarah, dan lain-lain. Rekening investasi menjadi dua yakni rekening investasi tidak terbatas dan terbatas. a) Rekening investasi tidak terbatas (general investment) Pemegang rekening jenis ini memberi wewenang kepada bank syariah unutk menginvestasika dananya dengan cara yang dianggap paling baik dan feasible, tanpa menerapakan pembatasan jenis, waktu, dan bidang usaha investasi. B) Rekening investasi terbatas Pemegang rekening jenis ini menerapkan pembatasan tertentu dalam hal jenis, bidang usaha, dan waktu bank menginvestasikan dananya.

3. Fungsi bank syariah sebagai Jasa keuangan Bank syariah dapat juga menawarkan berbagai jasa keuangan lainnya berdasakan upah (fee based) dalam sebuah kontrak perwakilan atau penyewaan. Contohnya, garansi, transfer kawat, L/C, dan sebagainya.

4. Fungsi bank syariah sebagai Jasa Sosial. Konsep perbankan islam/syariah mengharuskan bank islam melaksanakan jasa sosial, bisa melalui dana qardh (pinjaman kebaikan), zakat, atau dana sosial yang sesuai dengan ajaran Islam. Konsep perbankan syariah juga mengharuskan bank syariah memainkan peran dalam pengembangan sumber daya insani dan menyumbang dana bagi pemeliharaan serta pengembangan lingkungan hidup

\section{d. Peran Perbankan Syariah}


Undang-Undang No. 10 Tahun 1998 yang merupakan penyempurnaan atas Undang-Undang No. 7 Tahun 1992 tentang Perbankan, keberadaan bank syariah mulai diperhitungkan. Undang-Undang No. 10 Tahun 1998 memberikan ketegasan dan peluang yang besar bagi perkembangan bank syariah di Indonesia untuk tumbuh dan berkembang. Bank umum berdasarkan undang-undang diberi kesempatan untuk menjalankan dual banking system, yaitu penerapan sistem konvensional dan syariah sekaligus (Undang-Undang No. 10 Tahun 1998).

Bank syariah adalah bank yang menjalankan fungsi intermediasinya berdasarkan prinsip-prinsip syariat Islam. Peran dan fungsi bank syariah, di antaranya sebagai berikut : Sebagai tempat menghimpun dana dari masyarakat atau dunia usaha dalam bentuk tabungan (mudharabah), giro (wadiah), serta menyalurkannya kepada sektor riil yang membutuhkan. Sebagai tempat investasi bagi dunia usaha (baik dana modal maupun dana rekening investasi) dengan menggunakan alat-alat investasi yang sesuai dengan syariah. Seperti al-murabahah (pembiayaan jual beli barang), al-mudharabah pembiayaan bagi hasil), dan almusyarakah (pembiayaan penyertaan modal), Memberikan jasa sosial seperti pinjaman kebajikan (qardul hasan), zakat, dan dana sosial lainnya yang sesuai dengan ajaran Islam (http://simplenews05.blogspot.co.id/2015/08/peran-danfungsi-bank-syariah.html).

\section{e. Prinsip Dasar Perbankan Syariah}

Secara umum adalah melarang melakukan transaksi yang mengandung unsurunsur riba, maisir, gharar, dan jual beli barang haram. Prinsip bank syariah ini diterapkan untuk mencapai tujuan sesuai jalur syariah yaitu :

\section{Prinsip bank syariah (Mudharabah)}

Mudharabah adalah akad kerja sama usaha antara shahibul maal (pemilik dana) dan mudharib (pengelola dana) dengan nisab bagi hasil menurut kesepakatan di muka, jika usaha mengalami kerugian maka seluruh kerugian ditanggung oleh pemilik usaha, kecuali jika ditemukan adanya kelalaian atau kesalahan oleh pengelola dana, seperti penyelewengan, kecurangan dan penyalahgunaan dana. Secara umum, mudharabah dibagi menjadi dua jenis. yaitu: 1) Mudharabah Muthlaqah, yaitu bentuk kerja sama antara shahibul maal dan mudharib yang cakupannya sangat luas dan tidak dibatasi oleh spesifikasi jenis usaha, waktu dan daerah bisnis. 2) Mudharabah Muqayyadah, yaitu kebalikan dari mudharabah muthalaqah, yaitu si mudharib dibatasi dengan batasan jenis usaha. Adanya pembatasan ini seringkali mencerminkan kecenderungan umum si shahibul maal dalam memasuki jenis dunia usaha.

\section{Prinsip bank syariah (Musyarakah)}

Musyarakah adalah akad kerjasama atau pencampuran antara dua pihak atau lebih untuk melakukan suatu usaha tertentu yang halal dan produktif dengan kesepakatan bahwa keuntungan akan dibagikan sesuai dengan nisab yang disepakati dan resiko akan ditanggung sesuai dengan porsi kerjasama.

Jenis-jenis musyarakah ada empat, yaitu: a)Musyarakah Muwafadhah, yaitu kerjasama dua orang atau lebih pada suatu obyek dengan syarat tiap-tiap pihak memasukkan modal yang sama jumlahnya serta melakukan tindakan hukum (kerja) yang sama, sehingga tiap-tiap pihak dapat melakukan perbuatan hukum atas nama orang-orang yang bekerjasama itu. b) Musyarakah Al-Inan, kerjasama dalam modal dalam suatu perdagangan yang dilakukan dua orang atau lebih dan keuntungan 
dibagi bersama dengan jumlah modal yang tidak harus sama porsinya. c) Musayarakah Al-Wujuh, yaitu kerjasama yang dilakukan dua orang atau lebih yang tidak punya modal sama sekali dan mereka melakukan suatu pembelian dengan kredit serta menjualnya dengan harga tunai, sedangkan keuntungan yang diperoleh dibagi bersama. d) Musyarakah Al-Abdan, yaitu kerjasama yang dilakukan oleh dua pihak untuk menerima suatu perkerjaan, seperti pandai besi, servis alat-alat elektronik, laundry, dan tukang jahit. Hasil yang diterima dari pekerjaan itu dibagi bersama dengan kesepakatan mereka berdua.

\section{Prinsip bank syariah (Wadiah)}

Wadiah adalah titipan murni dari satu pihak kepada pihak lain, baik individu maupun hukum yang harus dijaga dan dikembalikan kepada si penitip kapan saja si penitip menghendaki. Dengan melihat prinsip dalam syariah Islam, wadiah dapat digolongkan menjadi dua macam yaitu: a) Amanah, yaitu pihak yang dititipi tidak boleh menggunakan atau memanfaatkan harta titipan. b) Dhamanah, yaitu pihak yang dititipi bertanggung jawab penuh terhadap keutuhan harta titipan, sehingga pihak yang dititipi boleh memanfaatkan harta titipan tersebut. Demikianlah beberapa penjelasan prinsip bank syariah.

\section{Perbandingan Perbankan Syariah dengan Perbankan Konvensional}

1. Perbedaan Falsafah. Perbedaan pokok antara bank konvensional dengan bank syariah terletak pada landasan falsafah yang dianutnya. Bank syariah tidak melaksanakan sistem bunga dalam seluruh aktivitasnya sedangkan bank kovensional justru kebalikannya. Hal inilah yang menjadi perbedaan yang sangat mendalam terhadap produk- produk yang dikembangkan oleh bank syariah, dimana untuk menghindari sistem bunga maka sistem yang dikembangkan adalah jual beli serta kemitraan yang dilaksanakan dalam bentuk bagi hasil. Pada dasarnya, semua jenis transaksi perniagaan melalui bank syariah diperbolehkan asalkan tidak mengandung unsur bunga (riba). Riba secara sederhana berarti sistem bunga berbunga atau compound interest yang dalam semua prosesnya bisa mengakibatkan membengkaknya kewajiban salah satu pihak seperti efek bola salju.

2. Konsep Pengelolaan Dana Nasabah. Dalam sistem bank syariah dana nasabah dikelola dalam bentuk titipan Maupun investasi.Cara titipan dan investasi berbeda dengan deposito pada bank konvensional di mana deposito merupakan upaya membungakan uang. Konsep dana titipan berartikapan saja nasabah membutuhkan, bank syariah harus dapat memenuhinya. Akibatnya dana titipan menjadi sangat likuid. Likuiditas yang tinggi inilah membuat dana titipan kurang memenuhi syarat suatu investasi yang membutuhkan pengendapan dana. Sesuai dengan fungsi bank sebagai intermediary yaitu lembaga keuangan penyalur dana nasabah penyimpan kepada nasabah peminjam, dana nasabah yang terkumpul dengan cara titipan atau investasi tadi kemudian dimanfaatkan atau disalurkan ke dalam traksaksi perniagaan yang diperbolehkan pada sistem syariah. Keuntungan dari pemanfaatan dana nasabah yang disalurkan ke dalam berbagai usaha itulah yang akan dibagikan kepada nasabah. Jika hasil usaha semakin tinggi maka semakin besar pula keuntungan yang dibagikan bank kepada nasabahnya. Namun jika keuntungannya kecil otomatis semakin kecil pula keuntungan yang dibagikan bank kepada nasabahnya. 
3. Kewajiban Mengelola Zakat. Bank syariah diwajibkan menjadi pengelola zakat yaitu dalam arti wajib membayar zakat, menghimpun, mengadministrasikannya dan mendistribusikannya. Hal ini merupakan fungsi dan peran yang melekat pada bank syariah untuk memobilisasi dana- dana sosial (zakat, infak, sedekah).

4. Struktur Organisasi. Di dalam struktur organisasi suatu bank syariah diharuskan adanya Dewan Pengawas Syariah (DPS). DPS bertugas mengawasi segala aktivitas bank agar selalu sesuai dengan prinsip- prinsip syariah. DPS ini dibawahi oleh Dewan Syariah Nasional (DSN). Berdasarkan laporan dari DPS pada masing - masing lembaga keuangan syariah, DSN dapat memberikan teguran. Jika lembaga yang bersangkutan menyimpang. DSN juga dapat mengajukan Rekomendasi kepada lembaga yang memiliki otoritas seperti Bank Indonesia dan Departemen Keuangan untuk memberikan sanksi. Dalam berbagai hal bank syariah dan bank konvesional memiliki persamaan, terutama dalam sisi teknis penerimaan uang, mekanisme transfer, teknologi komputer yang digunakan, persyaratan umum pembiayaan dan lain sebagainya. Akan tetapi juga banyak perbedaan mendasari antara keduanya. Secara umum perbedaan antara bank konvesional dan bank syariah sebagai berikut: (http://www.banksyariah.net/2012/07/prinsip-bank-syariah.html).

\begin{tabular}{|l|l|l|}
\hline \multicolumn{1}{|c|}{ Unsur } & \multicolumn{1}{|c|}{ Bank Syariah } & \multicolumn{1}{c|}{ Bank Konvesional } \\
\hline akad dan aspek legalitas & Hukum islam dan hukum positif & Hukum positif \\
\hline $\begin{array}{l}\text { lembaga penyelesaian } \\
\text { sengketa }\end{array}$ & $\begin{array}{l}\text { BadanAbritase Mu'amalat } \\
\text { Indonesia(BAMUI, Basyarnas) }\end{array}$ & $\begin{array}{l}\text { Badan Abritase Nasional } \\
\text { Indonesia }\end{array}$ \\
\hline Struktur oranisasi & $\begin{array}{l}\text { Ada Dewan Syari'at Nasional } \\
\text { (DSN) dan dewan Pengawas } \\
\text { Syariah (DPS) }\end{array}$ & Tidak ada DSN dan DPS \\
\hline Investasi & Halal & Halal dan haram \\
\hline Prinsip organisasi & Bagi hasil, jual beli, sewa & Perangkat bunga \\
\hline Tujuan & Profit dan falah oriented & Profit oriented \\
\hline Hubungan nasabah & Kemitraan & Debitur dan kreditur \\
\hline
\end{tabular}

Adapun perbedaan dari segi bunga dan bagi hasil dapat djabarkan sebagai berikut:

\begin{tabular}{|l|l|l|}
\hline No & \multicolumn{1}{|c|}{ Bunga } & \multicolumn{1}{c|}{ Bagi hasil } \\
\hline 1 & $\begin{array}{l}\text { Penentuan bunga dibuatpada waktu akad } \\
\text { dan asumsi harus selalu untung. }\end{array}$ & $\begin{array}{l}\text { Penentuan besarnya rasio atau nasabah } \\
\text { bagi hasil ibuat pada waktu akad dengan } \\
\text { berpedoman pada kemungkinan untung } \\
\text { rugi. }\end{array}$ \\
\hline 2 & $\begin{array}{l}\text { Besarnya presentase berdasarkan jumlah } \\
\text { uang dan modal yang dipinjamkan }\end{array}$ & $\begin{array}{l}\text { Besarnya rasio bgi hasil berdasarkan pada } \\
\text { jumlah keuntungan yang diperoleh. }\end{array}$ \\
\hline 3 & $\begin{array}{l}\text { Pembayaran bunga tetap seperti yang } \\
\text { dijalankan tanpa pertimbangan apakah } \\
\text { proyek yang dijalankan oleh pihk } \\
\text { nasabah utntung atau rugi. }\end{array}$ & $\begin{array}{l}\text { Bagi hasil bergantung pada keuntungan } \\
\text { proyek yang dijalankan. Bila usaha } \\
\text { merugi, keuntungan akan ditanggug oleh } \\
\text { kedua belah pihak. }\end{array}$ \\
\hline 4 & $\begin{array}{l}\text { Jumlah pebayaran bunga tia meningkat } \\
\text { sekalipun jumlah keuntungan berlipat } \\
\text { atau keadaan ekoomi sedan booming }\end{array}$ & $\begin{array}{l}\text { Jumlah pembagian laba meningkat sesuai } \\
\text { peingkatan jumlah pendapatan. }\end{array}$ \\
\hline
\end{tabular}


\begin{tabular}{l|l|}
\hline 5 & Eksistensi baunga diragukan(kalau tidak
\end{tabular} dikecam), oleh semua agama termasuk islam.

\section{Metode Pelaksanaan Pengabdian Masyarakat}

\section{a. Metode Pelaksanaan}

Rangkaian kegiatan pengabdian masyarakat adalah sebagai berikut:

1) Bentuk Kegiatan

Bentuk kegiatan yang dilakukan dalam sosialisasi tersebut adalah :

Pemaparan materi tentang perbankan syariah.

$>$ Pemahaman dan tanya jawab tentang perbankan syariah yang benar menurut ajaran Islam.

2) Tempat Kegiatan

Adapun tempat kegiatan atau lokasi kegiatan dilaksanakan di di Masjid

Nuruddin Desa Gelebak Dalam Kecamatan Rambutan Kabupaten Banyuasin Palembang

3) Proses Kegiatan

Adapun proses kegiatan dilaksanakan dalam waktu 2 hari pada hari Sabtu dan Minggu mulai tanggal 19 dan 20 September 2020. Adapun kegiatan yang dilakukan selama kegiatan berlangsung adalah sebagai berikut :

1. Tanggal 19 September 2020 :

Adapun kegiatan yang dilakukan pada pertemuan ke-1 adalah sebagai berikut :

a) Registrasi peserta

b) Penyampaian materi sesi I oleh Choiriyah, S.H.I., M.Pd.I. dengan judul materi pengertian perbankan syariah dan sejarah perbankan syariah

c) Penjelasan tentang Bank syariah dan Konvensional disampaikan oleh Choiriyah, S.H.I., M. Pd.I.

2. Tanggal 20 September 2020: Dilaksanakan pada pertemuan ke-2 adalah sebagai berikut :

a) Menyampaikan materi sesi II dilakukan oleh Choiriyah, S.H.I., M.Pd.I. dengan judul materi Peran Perbankan Syariah.

b) Penjelasan tentang Perbandingan Perbankan Syariah dan Konvensional, dibawakan oleh Choiriyah, S.H.I., M. Pd.I Tanya jawab tentang Perbankan Syariah

c) Doa dan penutup yang dibawakan oleh Saprida, M.H.I

\section{b. Waktu Kegiatan dan Materi Pokok dalam Kegiatan}

Pelaksanaan kegiatan dilakukan dalam waktu dua hari pada hari Sabtu dan Minggu Adapun jadwal pelaksanaannya adalah sebagai berikut :

\section{Tanggal 19 September 2020}

\begin{tabular}{|c|l|l|}
\hline Waktu & \multicolumn{1}{|c|}{ Materi } & \multicolumn{1}{c|}{ Narasumber } \\
\hline $09.00-09.30$ & - Registrasi peserta & Mahasiswi \\
\hline $09.30-10.00$ & - Pembukaan & Saprida, M.H.I \\
\hline $10.00-11.00$ & $\begin{array}{l}\text { Materi: } \\
\text { Pengertian Perbankan Syariah }\end{array}$ & Choiriyah, S.H.I., M. Pd.I \\
\hline $11.00-12.00$ & - Bank syariah dan Konvensional & Choiriyah, S.H.I., M. Pd.I \\
\hline $12.00-13.00$ & \multicolumn{2}{|c|}{ ISOMA } \\
\hline $13.00-14.00$ & $\begin{array}{l}\text { Materi: } \\
\text { - Sejarah Perbankan Syariah }\end{array}$ & Choiriyah, S.H.I.,M.Pd.I. \\
\hline
\end{tabular}


\begin{tabular}{|l|l|l}
\hline $14.00-15.00$ & - Tanya Jawab Bank Syariah & Choiriyah, S.H.I., M. Pd.I
\end{tabular}

Tanggal 20 September 2020

\begin{tabular}{|c|l|l|}
\hline Waktu & \multicolumn{1}{|c|}{ Materi } & \multicolumn{1}{|c|}{ Narasumber } \\
\hline $09.00-10.30$ & $\begin{array}{l}\text { Materi: } \\
-\quad \text { Peranan Perbankan Syariah }\end{array}$ & Choiriyah, S.H.I.,M.Pd.I. \\
\hline $10.30-12.00$ & $\begin{array}{l}\text { Perbandingan Perbankan Syariah } \\
\text { dan Konvensional }\end{array}$ & Choiriyah, S.H.I.,M.Pd.I. \\
\hline $12.00-13.00$ & \multicolumn{2}{|c|}{ ISOMA } \\
\hline $13.00-14.00$ & $\begin{array}{l}\text { Materi: } \\
- \text { Tanya Jawab }\end{array}$ & Choiriyah, S.H.I.,M.Pd.I. \\
\hline $14.00-15.00$ & - Doa dan penutup & Saprida, M.H.I \\
\hline
\end{tabular}

Total durasi pelaksanaan pengabdian pada masyarakat untuk masing-masing pelaksana adalah :

\begin{tabular}{|c|l|c|c|c|}
\hline No & \multicolumn{1}{|c|}{ Nama } & NIDN/NPM & Status & Durasi \\
\hline 1 & Choiriyah, S.H.I.,M.Pd.I. & 2123068201 & Dosen Perbankan & 36 Jam \\
\hline 2 & Saprida, M.H.I & 2114118401 & Dosen Ekonomi & 36 Jam \\
\hline 3 & Yeyen Priyanti & 201902008 & & \multirow{2}{*}{ Jam } \\
\hline 4 & Dinda Amira Putri & 201902003 & Mahasiswi & \\
\hline
\end{tabular}

\section{Hasil Pengabdian Pada Masyarakat}

Hasil dari kegiatan ini adalah memberikan wawasan kepada Masyarakat gelebak dalam tentang Perbankan Syariah di Masjid Nuruddin Desa Gelebak Dalam Kecamatan Rambutan Kabupaten Banyuasin Palembang mengenai perbankan syariah secara terperinci. Hasil yang ingin dicapai dari pelaksanaan kegiatan ini adalah sebagai berikut:1) Mengenalkan kepada para masyarakat Desa Gelebak Dalam Kecamatan Rambutan Kabupaten Banyuasin tentang perbankan syariah secara terperinci. 2) Berbagi ilmu kepada Masyarakat Desa Gelebak Dalam tentang kosep perbankan syariah serta fungsi perbankan syariah. 3) Mengenalkan peranan perbankan syariah, prinsip dasar serta perbandingan perbankan syariah dan konvensional. 4) Para peserta sosialisasi bisa memahami Bank Syariah. 5) Para peserta sosialisasi tanya jawab dan diskusi tentang perbankan syariah.

\section{Dokumentasi Kegiatan Pengabdian}

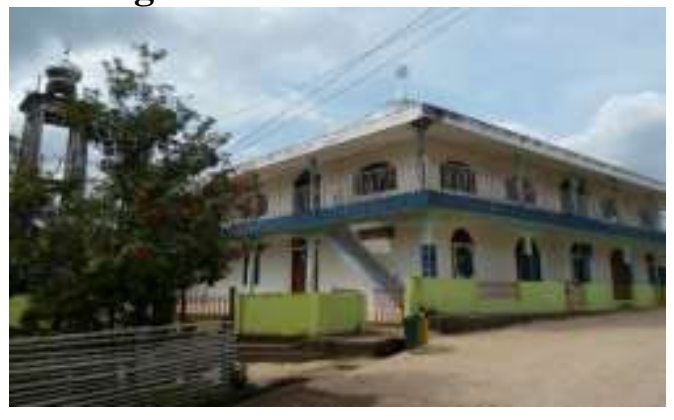

\section{Simpulan}

Berdasarkan beberapa kegiatan yang telah narasumber beserta panitia lakukan pada pengabdian masyarakat tentang Sosialisasi Perbankan Syariah ditengah 
Pandemi Covid-19 di Masjid Nuruddin Desa Gelebak Dalam Kecamatan Rambutan Kabupaten Banyuasin Palembang, maka dapat diambil beberapa kesimpulan :

1. Kegiatan ini sangat bermanfaat bagi peserta Sosialisasi Perbankan Syariah ditengah Pandemi Covid-19, Masyarakat membutuhkan tambahan pengetahuan tentang penerapan Perbankan Syariah secara benar menurut ajaran Islam.

2. Kegiatan pengabdian masyarakat ini juga membantu para peserta sosialisasi tentang Perbankan Syariah, Kosnep dasar perbankan syariah, Fungsi Perbankan Syariah, Peranan Perbankan Syariah, prinsip dan perbandingan perbankan syariah dan konvensional.

3. Meningkatkan pengetahuan Masyarakat bahwa dengan adanya perbankan Syariah saat ini bisa membantu masyarakat dalam menjauhi perbuatan haram dan dilarang dalam agama islam, untuk memberikan pelayanan yang adil dan merata dalam memperbaiki perekonomian seluruh masyarakat.

4. Para peserta sosialisasi memahami peranan Perbankan Syariah

5. Seluruh masyarakat desa gelebak dalam yang mengikuti sosialisasi Perbankan Syariah melakukan diskusi dan tanya tanya secara menyeluruh tentang Perbankan Syariah.

\section{Daftar Pustaka}

Al-quranul Karim

Antonio, Muhammad Syafi'i. 2001. Bank Syariah Dari Teori Ke Praktik. Jakarta : Gema Insani.

Imamul Arifin, Giana Hadi Wagiana ; penyunting, Ayatullah Khomaeni, Akhbar Wahidin. 2009. Jakarta : Pusat Perbukuan, Departemen Pendidikan Nasional.

Muhammad, 2005. Teknik Perhitungan Bagi Hasil dan Profit Margin pada Bank Syariah. Yogyakarta, UII Press.

Muhammad Ridwan, 2004. Manajemen Baitul Maal Wa Tamwil, Yogyakarta : UII Press

M. Syafi'i Antonio, 2006. Dasar- Dasar Manajemen Bank Syariah, Jakarta: Pustaka Alfabeta, cet ke-4.

Nurul Huda dan Muhamad Heykal. 2013. Lembaga Keuangan Islam Tinjauan Teoretis Dan Praktis. Jakarta : Kencana Prenada Media Group

Undang-undang Republik Indonesia No. 10 tahun 1998 tentang Perbankan di Indonesia

Undang-undang Republik Indonesia No. 21 Tahun 2008 tentang Perbankan Syariah Wangsawidjaya, 2012. Pembiayaan Bank Syariah, Jakarta: Gramedia Pustaka Utama.

\section{Bahan dari internet :}

http://www.banksyariah.net/2012/12/fungsi-bank-syariah.html diakses tgl 1 september 2020 jam 11.00 wib 
https://fachriadha55.blogspot.co.id/2017/03/silabus-makul-bank-dan-lembagakeu.html diakses tgl 1 september 2020 jam 13.40 wib

https://core.ac.uk/download/pdf/148617413.pdf, diakses tgl 1 september 2020 jam $14.00 \mathrm{wib}$ 
Sasialisasi Perbankan Syariah Ditengah Pandemi Cavid-19 Di Masjid Nuruddin Desa Gelebak Dalam

Kecamatan Rambutan Kabupaten Banyuasin Palembang

Choiriyah 